\title{
MAFIC DYKES: RELATIONSHIPS AMONG GEOMETRY, INTERNAL FRACTURES AND FISSURAL TECTONIC PATTERNS
}

\author{
L.C.Corrêa-Gomes' \\ M.N. de Souza ${ }^{2}$ \\ D.R. Corrêa ${ }^{2}$ \\ I.R. Silva ${ }^{3}$ \\ A.C.S. Falcão \\ M.L.P.Cobucci ${ }^{3}$ \\ K.T.Ishioka ${ }^{4}$ \\ A.R.Espineira ${ }^{3}$ \\ J.W.O.Moraes ${ }^{3}$
}

\section{INTRODUCTION}

The understanding of systems associated with the genesis and evolution of mafic dykes presumes comprehension of the phenomena that control (i) the formation and development of the fracture-conduit, (ii) the associated stress field, and (iii) the tectonic regime prevalent at a particular time.

Several experiments on material deformation (e.g. on rocks, halite and clay) indicate that fractures begin as locally concentrated small tension nuclei (RECHES, 1983, 1988; RECHES \& DIETRICH, 1983). The length of a fracture depends on its deformation-propagation velocity, low velocities favouring short length and coalescence phenomena (OLSON \& POLLARD, 1989; POLLARD,

\footnotetext{
'Escola T6cnica Federal da Bahia, Universidade Federal da Bahia, Rua Caetano Moura, 123, 40210 Salvador, BA, Brazil.

${ }^{2}$ Universidade Federal da Bahia, Rua Caetano Moura, 123, 40210 Salvador, BA, Brazil.

${ }^{3}$ Escola Técnica Federal da Bahia, 40210 Salvador, BA, Brazil.

"Universidade Católica, 40210 Salvador, BA, Brazil.
} 
1973); this is specially true when linear and parallel concurrent fracture pairs are formed (SEGALL \& POLLARD, 1980).

On the other hand, the filling or not of a fissure is determined by relations among shear stress (Ss), tension stress $(T s)$, fluid pressure $(F p)$ and lithostatic pressure $(L p)$. When $S s>T s+$ $F p$, the fissure will not be filled; if $S s<T s+F p$, filling will occur; and under the special condition of $F p$ $>S s+L p$ the emplacement will take place under conditions of hydraulic fracturing (POLLARD \& HOLZHAUZEN, 1979; BEACH, 1980; COX \& ETHERIDGE, 1989).

The distensive tectonic situation appropriate for dyke formation is obtained mainly under three conditions: a) domal upflift (BHATTACHARY \& KOIDE, 1987; WILSON, 1973); b) linear extension by pure shear (RUPELL et al., 1988); c) transtension by simple shear (CHOROWICZ et al., 1987; ZALAN, 1986; DENG et al., 1986). Each case can be revealed at different scales by the distribution, shape and structures associated with mafic dykes. Good examples of well-preserved mafic dykes along the coast of the city of Salvador, Bahia, permit successful analysis of such relationships.

\section{LOCATION AND METHODOLOGY}

The mafic dykes of the Salvador region are intrusive into $2.0 \mathrm{Ga}$ granulite and amphibolite-grade metamorphic rocks. Dykes are c. $1.0 \mathrm{Ga}$ old (D'AGRELLA-FILHO et al., 1989) and range from a few centimeters to $47 \mathrm{~m}$ thick. They strike $\mathrm{N} 130^{\circ}$ to $\mathrm{N} 160^{\circ}$ with subvertical NE dips. The main dyke occurrences are found on the beaches of Vitória, Itapoan, Pituba, Ondina, Barra, Rio Vermelho (RV) and Amaralina districts (Fig. 1). The last three have been chosen for this study because of the diversity of information gathered and their accessibility.

A large amount of data (2636 measurements altogether) on internal cooling joints, contact planes, enclaves, country rock foliation as well as planar and linear elements related to the dyke history of emplacement and chill has been collected.

\section{DEVELOPMENT OF DYKE FORMS AND ASSOCIATED STRUCTURES}

The great variety of cooling joint positions and dyke forms reveals a complex rheologic-tectonic situation and sequence of formation. Some of the most common geometries observed are shown in Figure 2. They are: 1) bifurcate, with an angle of $30^{\circ}$ between the principal 


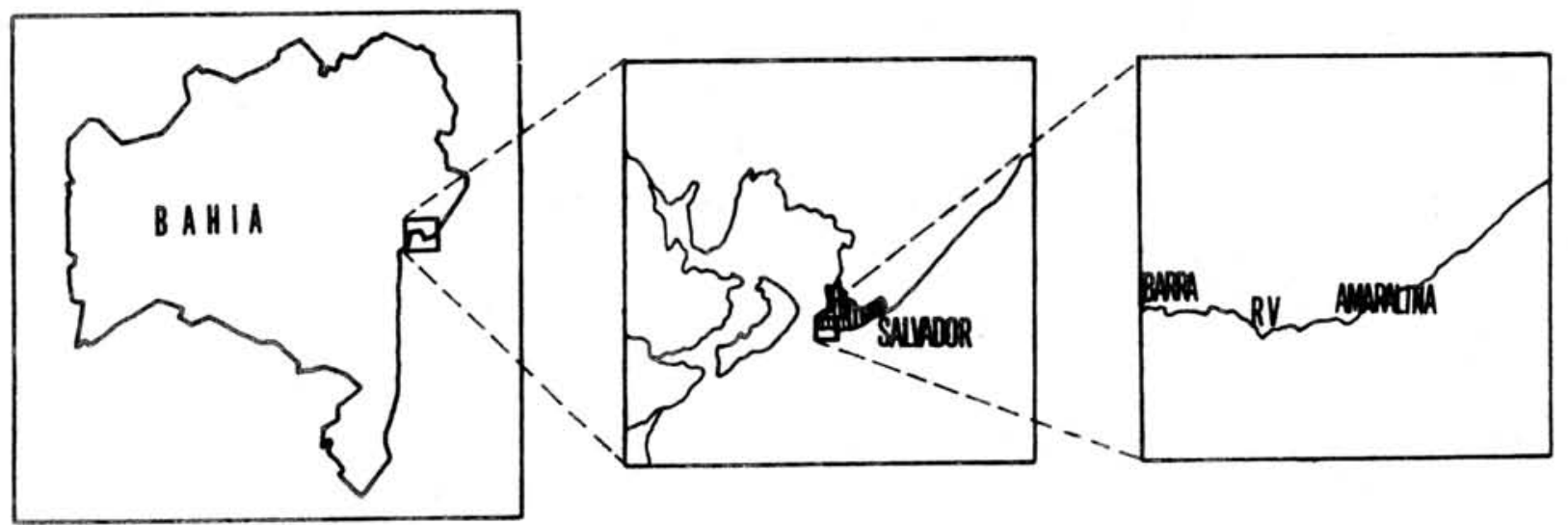

Figure 1 - Location of the study area. See text for details.

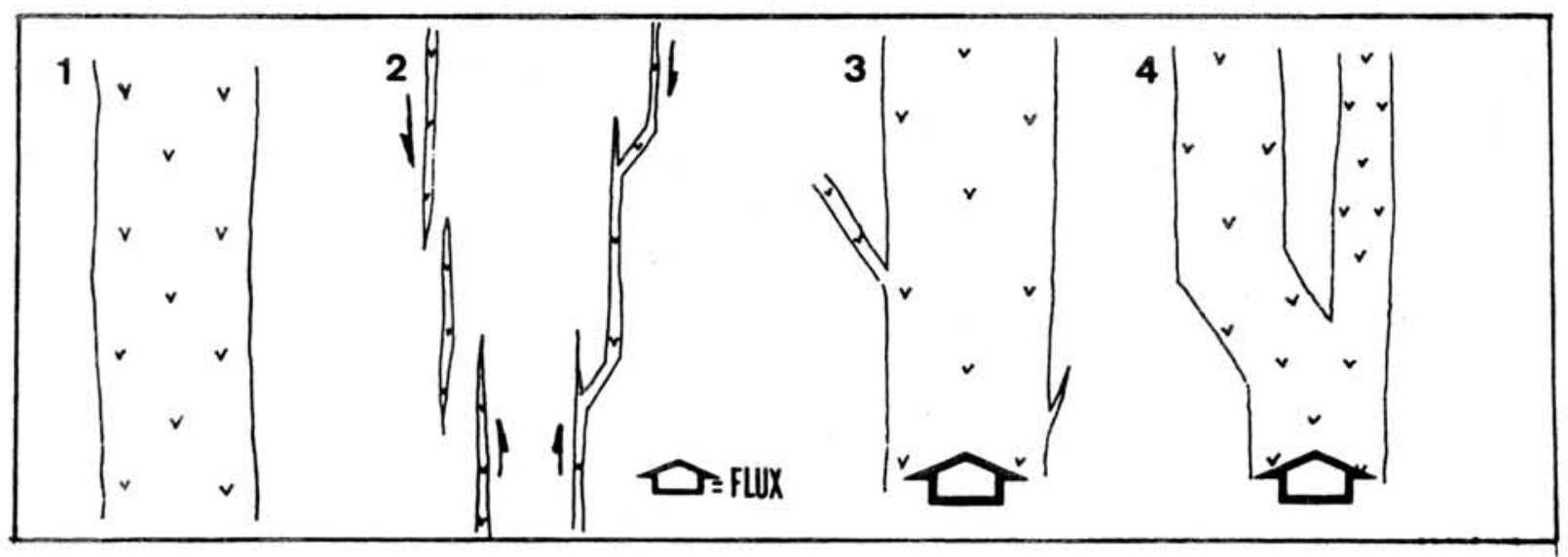

Figure 2 - Principal forms of mafic dykes from the Salvador cosstline. 1) Tabular, Barra. 2) Lenticular and "zig-zag", Amaralina. 3) Blfurcated, with narrow branches, Rio Vermelho. 4) Blfurcated, with large branch, Amaralina. 
body and lateral branch; 2) tabular, with uniform thickness; 3) lenticular, with acute terminations, emplaced within "en echelon" fractures; 4) "zig-zag", where coalescence of fracture pairs are frequent; 5) "bent forms"; and 6) "L-shaped" forms, having $90^{\circ}$ angles between principal and lateral branches which terminate abruptly.

Form 6 indicates an important action of $F p$ in the formation of orthogonal ramifications. Form 5 can be explained by fissure refraction before or during magma intrusion with a significant role played by $\mathrm{Fp}$ in the latter situation (MOTOKI et al., 1988; MANDL, 1987; POLLARD, 1973). Different circumstances, probably a transtensional system are required to explain forms 4 and 3. Linear extension can account for the geometry of forms 2 and 1 by transtensional or domal uplift systems. Forms 1-4 can define local or regional situations, whereas 5 and 6 represent local behaviour only.

In the case of cooling joints, two sets, both vertical to subvertical, deserve special emphasis: longitudinal fractures $(L)$, which parallel the dyke strike, and transverse fractures $(T r)$ which parallel the dip direction and are often orthogonal to $L$.

The geometric behaviour of the joints is also variable within the conduits: 1) parallel (L) and orthogonal (Tr) (Fig. 3.1); 2) parallel and orthogonal on dyke margins, passing abruptly to diagonal in the centre (Fig. 3.2); 3) parallel and orthogonal on margins, progressively curving until the become diagonal in the centre (Fig. 3.3) and 4) both diagonal (Fig. 3.4).

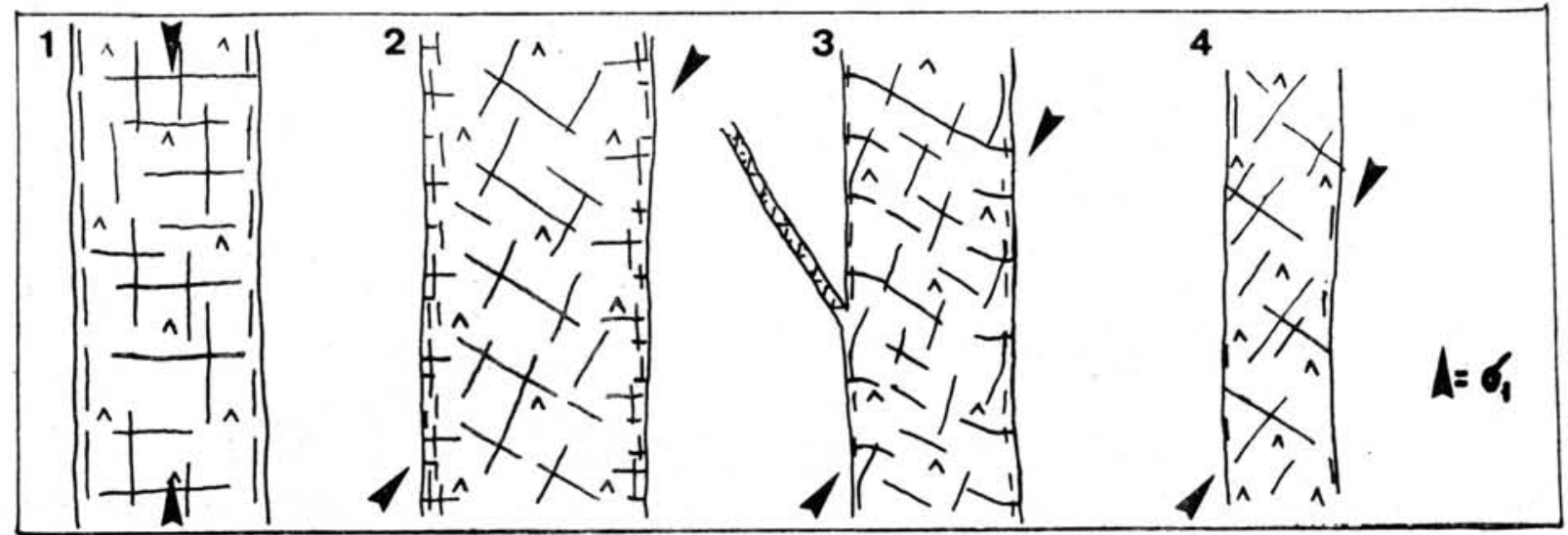

Figure 3 - Orientation of cooling joints in dykes. 1) Parallel and orthogonal to conduit margins. 2) Parallel and orthogonal at margins, and diagonal in the centre. 3) Progressively curving inwards. 4) Diagonal. Arrows indicate the principal tensor position. 
The conduit form and the tensor positions during magma solidification are the most important factors that control the oriented formation of internal joints in mafic dykes. For example, the orientation in Figure 3.1 indicates parallelism between the main tensor $\left(\right.$ sigma $_{1}$ ) and the dyke geometry, whereas in the other illustrated examples this condition holds only in the initial phases of conduit opening, after which, the tensor goes to a diagonal position. Two aspects are worth mentioning here: firstly, example 3.1 indicates an undisturbed tectonic setting, whereas the others reflect an unstable regime (CORREAA GOMES et al., 1988). Secondly, example 3.2 is observed in dykes 1 to $3 \mathrm{~m}$ thick; 3.3 in intrusions thicker than $3 \mathrm{~m}$; and 3.4 in dykes a few centimetres thick.

Good exposures of cooling joints in dykes occur on the beach near the Meridien hotel, Rio Vermelho district. Joint types shown i Figures 3.2, 3.3 and 3.4 can be found there in dykes with thicknesses $1.5 \mathrm{~m}, 26.0 \mathrm{~m}$ and $4-8 \mathrm{~cm}$, respectively. Possibly all dykes have solidified under oblique tension conditions, and owing to a delay in total magma solidification (longer times for thicker dykes), the different fracture patterns appear to reflect differing histories of rotation of the principal tensor. This observation is an accordance with results of FABRE et al. (1989) that indicate a total consolidation time of 4 to 6 days for a dyke $1 \mathrm{~m}$ thick, emplaced in shallow crustal conditions.

A special case in the Rio Vermelho area elucidates at the same time both the system of dyke formation and the importance of the tensors on the orientation of cooling joints (Fig. 4). A parallel pair of vertical veins, $8.0 \mathrm{~cm}$ thick, is interconnected by a third vein of sigmoidal shape. The planes occupied by the pair $\left(\mathrm{N}_{135^{\circ}}\right)$ represent two sinistral shear planes. With shear attenuation, $\mathrm{Fp}$ became more important than Ss, and the magma filled these planes, while the weak Ss caused rotation of the $L$ joints. Later, the principal tensor became parallel to the pair of veins, leading to internal fracturing of the central vein $\left(\mathrm{N} 95^{\circ}\right)$ that was formed under hydraulic fracturing conditions.

\section{CONCLUSIONS}

Some important conclusions can be drawn from the study of the mafic dykes of Salvador. The cooling joint positions in the veins are diagonal, principally in their central portions, and not parallel or orthogonal as expected. This happened because the position of the principal tensor influenced the system during solidification.

Different thicknesses and times of consolidation are the most important factors during the distinct geometric evolution of cooling joints, under conditions of principal tensor rotation. 


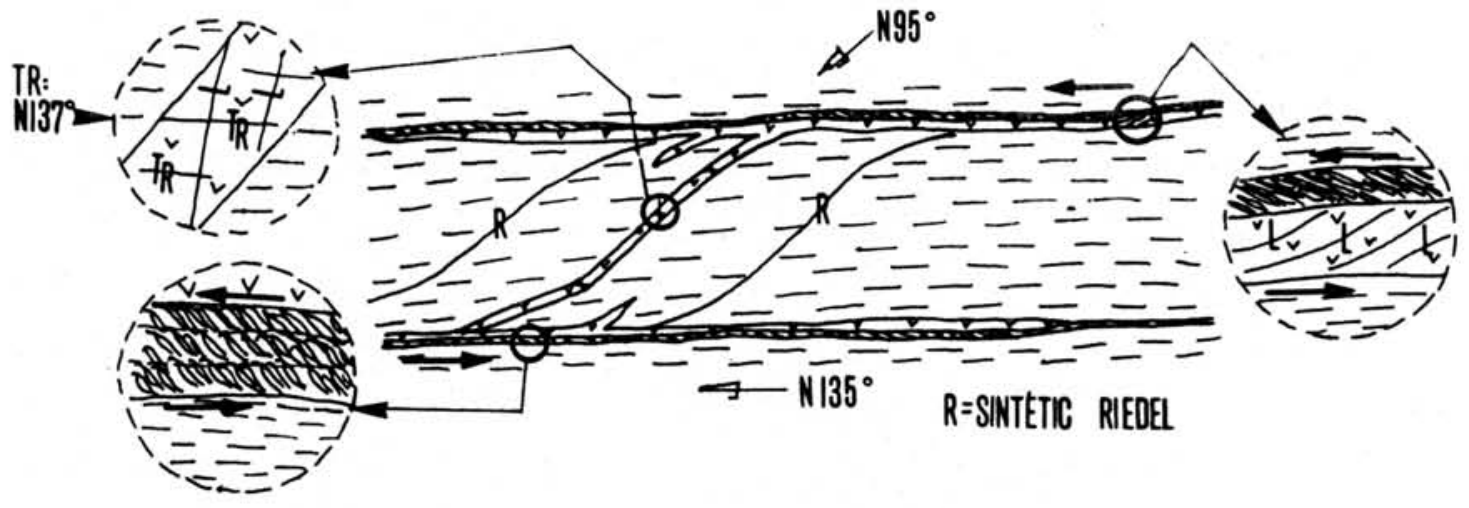

Figure 4 - Parallel mafic veins joined by sigmoidal vein, as the result of sinistral shear and posterior filling. Note that cooling joints of the parallel pair of vein (N135 ) and sigmoidal vein (N95 ) are diagonal (See text for details).

$T R=$ Transverse fractures. $L=$ Longitudinal fractures.

The isotopic dating of these dykes represents not only the emplacement age but also the age of the transtensional tectonism associated with this process.

Combining all information about shapes and internal fractures of the dykes, it is possible to suggest the most adequate tectonic setting that affected this area approximately $1.0 \mathrm{Ga}$ ago. Linear tension due to pure shear, associated or not with domal uplift, would be one of the tectonic regimes chosen; but the principal regime was, without a doubt, transtensional as evidenced in almost all the dykes studied.

Furthermore, the abundance of bifurcated, bent and orthogonal forms reveals the important influence of $F p$ on the dyke geometries in parallel and/or wedge zones.

The result of this comparison between emplacement planes and fracture rotation systems is that the majority of dykes were emplaced under dextral reverse shear regimes.

\section{REFERENCES}

BEACH, A. (1980) Numerical models of hydraulic fracturing and the interpretation of syntectonic veins. 
Journal of Structural Geology, 2(4):425-438.

BHATTACHARY, S. \& KOIDE, H. (1987) Theoretical and experimental studies of mantle upwelling, penetrative magmatism and development of rifts in continental and oceanic crusts. Tectonophysics, 143:13-30.

CHOROWICZ, J.; Le FOURNIER, J.; VIDAL, G. (1987) A model for rift development in Eastern Africa. Geological Journal, 22:495-513.

CORRÊA GOMES, L.C.; TANNER de OLIVEIRA, M.A.F.; LEAL, L.R.B. (1988) Feições estruturais dos diques máficos - relações entre o magmatismo fissural e as condições geológicas do meio. In: CONGRESSO BRASILEIRO DE GEOLOGIA, 35., Belém, 1988. Anais. V.5, p.2217-2226.

COX, S.I. \& ETHERIDGE, M.A. (1988) Coupled grain scale dilatancy and mass transfer during deformational high fluid pressures: examples from Mont, Lyell, Tasmania. Journal of Structural Geology, 11(1/2):147-162.

D'AGRELLA-FILHO, M.S.; PACCA, I.G.; ONSTOTT, T.C.: RENNE, P.R.; TEIXEIRA, W. (1989) estado atual da cooperação USP/Princeton University: resultados paleomagnéticos e geocronológicos em diques máficos das regiōes de Salvador, Olivença e Uauá, Cráton do São Francisco. In: WORKSHOP DIQUES MÁFICOS PRECAMBRIANOS DO BRASIL São Paulo, 1989. Boletim especial trabalhos apresentados. São Paulo, IUGS, UNESCO (Projeto PICG-257).

DENG, Q.; WU, D.; ZHANG, P.; CHEN, S. (1986) Structure and deformation character of strike-slip fault zones. Pageoph., 124(1/2):203-223.

FABRE, P.; KAST, Y.; GIROD, M. (1989) Estimation of flow duration of basaltic magma in fissures. Journal of Volcanology and Geothermal Research, 37:167-186.

MANDL, G. (1987) Discontinuous faul zones. Journal of Structural Geology, 9(1):105-110.

MOTOKI, A.; VILA, C.A.; ROIG, H.L (1988) Estudos litológicos e geológicos dos corpos intrusivos tabulares no município de Arraial do Cabo-RJ. In: CONGRESSO BRASILEIRO DE GEOLOGIA, 
35., Belém, 1988. Anais. Belém, SBG. V.6, p.2727-2739.

OLSON, J. \& POLARD, D.D. (1989) Inferring paleostresses from natural fracture patterns: a new method. Geology, 17:345-348.

POLLARD, D.D. (1973) Derivation and evaluation of mechanical model for sheet intrusion. Tectonophysic8, 19:233-269.

POLLARD, D.D. \& HOLZHANSEN, G. (1979) On the mechanical interaction between a fluid filled fracture and earth's surface. Tectonophysics, 53:27-57.

RECHES, Z. (1983) Faulting of rocks in thre日-dimensional strain fields. II - theoretical analysis. Tectonophysics, 95:133-156.

RECHES, Z. (1988) Evolution of fault patterns in clay experiments. Tectonophysics, 145:141-156.

RECHES, Z. \& DIETRICH, H.J. (1983) Faulting of rocks in threө-dimensional strain fields. I-Failure of rocks in poliaxial servo-control experiments. Tectonophysics, 95:111-132.

RUPELL, C.; ROYDEN, L; HODGES, K.V. (1988) Thermal modeling of extensional tectonics: application to pressure-temperature-time histories of metamorphic rocks. Tectonics, 7(5):947-957.

SEGALL, P. \& POLLARD, P. (1980) Mechanism of discontinuous faults. Journal of Geophysical Research, 85(138):4337-4350.

WILSON, T. (1973) Mantle plumes and plate motions. Tectonophysics, 19:149-164.

ZALAN, P.V. (1986) A tectônica transcorrente na exploração de petróleo, uma revisão. Revista Brasileira de Geociências, 16(3):245-257. 